\title{
Carrying capacity of maize as cattle feed in North Sulawesi, Indonesia
}

\author{
Paulus C. Paat, Derek Polakitan, Ratri Retno Ifada, and J.H.W. Rembang \\ North Sulawesi Assessment Institution for Agricultural Technology, Jl. Kampus Pertanian Kalasay, \\ Manado
}

\begin{abstract}
North Sulawesi is one of the production centers of cattle as well as maize in Indonesia. On the other hand, there is problem in cattle grazing decrease causing some farmers cultivate maize as a forage, even though this it is still cultivated carelessly so that the biomass productivity is low. This study aimed to evaluate the use of applied innovations in maize cultivation as forages. The Demonstration plot was conducted in Kembuan, Minahasa Regency at elevation of $700 \mathrm{~m}$ above the sea, in June-October 2019. The method used Technology Display, where the innovation package included recommended maize cultivation such as superior seeds, fertilizers, pesticides and tractor using. Fertilizing in 12 dap, Urea $250 \mathrm{~kg}+$ NPK (15-15-15) 150 $\mathrm{kg}$, then in $60 \mathrm{dap}$, Urea $125 \mathrm{~kg}$ and NPK (15-15-15) $100 \mathrm{~kg}$. Weeding using herbicides at 30dap. Harvesting as fresh forage, all biomass at 75 dap, 35.64 tons/ha with TDN content $20.54 \mathrm{t} / \mathrm{ha}$ (58\%) and provided a carrying capacity 11.34 UT, providing feed along the year. Financial analysis indicated the feasibilities, ROI coefficient 2.27 and BC Ratio 1.27. It can be concluded that maize farming can be a solution of forage fodder in cattle commodity areas.
\end{abstract}

\section{Introduction}

North Sulawesi Province is one of the Indonesian production centres for beef cattle. The Indonesian Minister of Agriculture Decree No. 472 of 2018 assigned three regencies in North Sulawesi as The Beef Cattle National Region, namely: (1) Minahasa, (2) Minahasa Selatan, and (3) Bolaang Mongondow [1]. In 2020 the cattle population in the province was 128.654 heads [2]. It decreases compared the cattle population in the 1993 was reached 300 thousand heads [3].

Cattle farms in North Sulawesi are facing many problems yet, therefore, it is difficult to move from the slump in population, production, productivity and product quality [4]. Various studies have found that one of the dominant root problems is feed. The feed problems of cattle farming in North Sulawesi due to the habit of farmers generally applying traditional extensive-grazing system based on grazing land [5]. This kind of maintenance system is gradually under pressure because the dimensions of the grazing space are decreasing due to the incessant expansion of the area of food crops, industrial plants, etc.

Based on these problems solution, the introduction of innovations in the high yielding forages is an alternative solution to be considered. In several beef cattle production centres in Minahasa Regency, cattle breeders cultivate maize not only to produce maize grains but 
also as forage for cattle consists of all plant biomass. Although this habit has been conducted for a long time, the farmers still cultivate it in a small portion, therefore, the biomass productivity is not optimal yet. There are many maize cultivation technology packages available, such as the Maize Integrated Crop Management Approach which usually call as "PTT-Jagung" recommended by the Research and Development Centre for Food under Ministry of Agriculture [6].

This study aims to evaluate the performance of implementing Integrated Plants Management, IPM (PTT-Jagung) as forage, especially on the total biomass yield, total nutrition, and forages technological package and its financial feasibilities that can be recommended as an alternative forage for cattle to solve feed problems and to support the development of beef cattle in North Sulawesi.

\section{Methodology}

\subsection{Research site and materials}

The field technology display was carried out in Kembuan Village, North Tondano District, Minahasa Regency - North Sulawesi Province in an elevation of $700 \mathrm{~m}$ above the sea during June - October 2019. The maize land area was 0.5 ha, open field, slope about $5 \%$ assuming soil nutrient status, the transmission of sunlight, and the rate of evaporation of water were homogeneous. The materials used were Superior Variety, Bisi 222, fertilizers: Urea and NPK (15-15-15), pesticides, tractors.

\subsection{Design experiment and management of the crop}

One package of the maize IPM is designed to produce maize as forage introduced in the technology field display. It was modified according to the specific conditions. The components of technology included: pre-tillage using pre-growth herbicide, tillage by using tractor once (plow and rotary); hybrid seeds (the commercial Bisi-222 variety), 75 x $20 \mathrm{~cm}$ in spacing (the population 66,000 plants per ha), two seeds per hole. Furthermore, the components of fertilization technology included: balance fertilization according to "PUTK soil analysis", the first application at 12 days after planting (dap) using of $250 \mathrm{~kg}$ Urea and $150 \mathrm{~kg}$ NPK 915-15-15), while the second application was carried out at 60 dap using 125 $\mathrm{kg}$ Urea and $100 \mathrm{~kg}$ NPK (15-15-15). Weeding technology used herbicides pre-tillage and at the age of 30 dap.

Harvesting maize as fresh forage was carried out at the age of 75 dap by taking almost all of the maize biomass, leaving only the base of the tree trunk about $3-5 \mathrm{~cm}$ above the ground. As a considerations of determining the harvest age at 75 dap, including: (i) achieving total dry matter yield and optimal nutritional quality, (ii) the best physiological status of maize plants for silage raw materials, and (iii) palatability ( preference of livestock to consume) if the feed is directly served fresh without any treatment [7].

\subsection{Data analysis}

Data analysis was carried out on the total biomass of fresh maize, the proportion of maize cobs and maize straw, by taking samples from 10 sampling points determined by the Quadrant Method or Plotless method [8], each sampling point has 3 plants. The total biomass of fresh maize is all parts of the harvested plant which include tree trunks, leaves and cobs which are weighed at once. The definition of cobs in this context is whole maize fruit 
consisting of husk and grains that are still attached to the stem, while maize straw is the total biomass of maize unless the cobs.

The value of the proportion of plant parts is calculated mathematically adopting the Proportion Formula compiled [9] with adjustments, as follows:

Cob proportion value to total maize biomass:

$$
X t i=\frac{X t i}{\left(\sum X b i\right)} X 100 \%
$$

Where:

$\mathrm{Xti}=$ weight of the $\mathrm{i}^{-{ }^{\text {th }}}$ cob

$\mathrm{Xbi}=$ total weight of the $\mathrm{i}^{-{ }^{\text {th }}}$ biomass

Value of Straw proportion to total maize biomass:

$$
X j i=\frac{X j i}{\left(\sum X b i\right)} X 100 \%
$$

Where:

$\mathrm{Xji}=$ weight of the $\mathrm{i}^{\text {th }}$ straw

$\mathrm{Xbi}=$ weight of the $\mathrm{i}^{-{ }^{\text {th }}}$ total biomass

The indicator of the success of maize farming performance for forage cattle is determined by the amount of profit received. The difference between farmers' income and expenditure is the net profit of the business $[10,11]$. Then, to evaluate the financial feasibilities was using BC Ratio analysis and ROI Analysis as follows [12]

$$
R / C=\text { Revenue/(Production Cost) }
$$

$\mathrm{R} / \mathrm{C}$ value $>1$, indicating that the business is financially feasible, because the amount of revenue is greater than the amount of expenditure. In addition to using the cost and income ratio (Revenue Cost Ratio $=\mathrm{R} / \mathrm{C}$ ) a feasibility analysis is also carried out through the efficient use of capital Return of Investment or ROI with the formula [13, 14], as follows:

$$
\text { ROI }=\text { Revenue } /(\text { Total Cost }) \times 100 \%
$$

The ROI criteria of a business are: value $>1$ is profitable farming, value $<1$ is not profitable, while value $=1$ is break-even farming.

\section{Results and discussion}

\subsection{Amount of biomass, proportion of straw and maize cobs}

The results of the analysis of fresh weight of biomass, cobs, and maize straw per clump at harvesting age of 75 dap were shown in Table 1 . The average biomass weight per maize clump of the Bisi-222 hybrid variety was $2.44 \mathrm{~kg}$ with an interval of 1.68 to $2.98 \mathrm{~kg}$. The average weight of fresh cobs per clump of maize hybrid variety Bisi-222 is $0.98 \mathrm{~kg}$, with an interval between 0.64 to $1.52 \mathrm{~kg}$, while the average weight of fresh straw per clump of maize hybrid variety Bisi-222 is $1.45 \mathrm{~kg}$, with an interval between 0.97 and $1.90 \mathrm{~kg}$. 
Table 1. Fresh weight of biomass and maize cobs per clump in $75 \mathrm{dap}(\mathrm{kg})$

\begin{tabular}{|l|c|c|c|}
\hline $\begin{array}{l}\text { Replication } \\
(\mathbf{n}=\mathbf{3})\end{array}$ & Biomass Weight & Cobs Weight & Straw Weight \\
\hline 1 & 2.81 & 1.14 & 1.67 \\
\hline 2 & 2.68 & 0.78 & 1.9 \\
\hline 3 & 2.98 & 1.08 & 1.91 \\
\hline 4 & 2.42 & 1.04 & 1.38 \\
\hline 5 & 2.93 & 1.11 & 1.82 \\
\hline 6 & 1.69 & 0.65 & 1.04 \\
\hline 7 & 2.20 & 0.91 & 1.29 \\
\hline 8 & 1.83 & 0.80 & 1.04 \\
\hline 9 & 2.50 & 1.52 & 0.98 \\
\hline 10 & 2.40 & 0.89 & 1.52 \\
\hline Average & 2.44 & 0.99 & 1.45 \\
\hline$\%$ & 100 & 40.47 & 59.53 \\
\hline
\end{tabular}

It is also shown in Table 1, the proportion of fresh maize cob and straw of the Bisi-222 hybrid variety to biomass weight. It can be seen that the average proportion of maize cobs is $40.47 \%$ with an interval between $31 \%$ to $61 \%$. Meanwhile, the proportion of maize straw is $59.53 \%$ with an interval between $40 \%$ to $64 \%$.

The biomass weight per clump of hybrid variety, $2.44 \mathrm{~kg}$ obtained in this study was still lower than the biomass per clump of maize hybrid variety Bima- 1 of $3.20 \mathrm{~kg}$. One of the advantages of the Bisi-222 variety where it's compared with Bima-1 variety is the proportion of cobs which reached $40.47 \%$ of the total biomass compared to the Bima-1 variety which was only 31.85 .

The use of fresh weight or fresh ingredients as shown in (Table 1) is indeed very practical to use among farmers but has a weakness in terms of precision compared to using dry matter (DM) basis. From the aspect of nutrition science, generally the calculation of feed requirements is using the basis of DM (dry matter-based diet). In this technology display activity, due to limited facilities, the DM analysis was not be carried out. To estimate the amount of DM content of maize biomass, a $22 \%$ BK content of maize biomass was used as reported by [15].

The maize biomass productivity calculated based on DM was $0.54 \mathrm{~kg}$ per clump obtained from the product of the average fresh biomass weight of $2.44 \mathrm{~kg}$ per clump (Table 1) and BK content of $22 \%$. Furthermore, the number of dry matters yields per clump is multiplied by the total plant population per ha of 66,000 clumps, the yield of forage maize hybrid variety Bisi-222 is 35.64 tons DM. In this case, by using the same calculation method, the yield of maize cobs and maize straw was $14.34 \mathrm{t}$ DM per ha and 21.05 t DM per ha, respectively.

The yield of forage maize hybrid variety Bisi-222 of $35.64 \mathrm{t}$ DM in this research was not significant different from the research results on several new varieties high-biomass maize reported [16], namely Bima-1 of 36.0 tons DM, Semar-10 of 35.52 tons DM, and Bisi-2 of 31.68 tons DM.

From the results of the DM forage, the estimated carrying capacity of cattle for 1 ha of maize land can be calculated, as shown in Table 2. In this Table 2 has shown that the carrying capacity per 1 ha of maize is 11.34 AU for the scenario of only one planting per season (1 crop index), $22.72 \mathrm{AU}$ for scenario only 2 crop index per year. The next alternative is assuming irrigation water is available or dry land pumping innovation, then for scenario 3 crop index per year the carrying capacity is $33.41 \mathrm{UT}$, and for scenario 4 crop index per year 44.55 UT.

Every single season of planting maize for fresh forage only takes about 85 days, including the land processing period as preliminary period. For that scenario 4 crop index per year is 
possible. As a comparison, maize farming for the purpose of producing dry maize grains generally takes about 100 days, besides the time required for land processing.

It can be seen (Table 3) that the data on the estimation of the carrying capacity of straw biomass if maize cobs are removed earlier, this is possible if in certain cases when farmers want to use maize cobs not for feed but for other purposes. Carrying capacity per 1 ha of maize straw is 6.58 AU for scenario 1, 13.16 AU for scenario 2, 19.73 AU for scenario 3, and 26.31 AU for scenario 4. One of the disadvantages of maize straw or plant parts of leaves and stems that lose the cob is the low carbohydrate content. The content of carbohydrates in the form of extract material without Nitrogen (BETN) maize grains is about $80 \%$ while maize straw is only $48.90 \%$ [7].

Table 2. Estimation of forage carrying capacity of maize biomass (DM based)

\begin{tabular}{|ll|l|l|}
\hline & $\begin{array}{c}\text { Crop index scenario } \\
\text { per year*) }\end{array}$ & \multicolumn{1}{|c|}{$\begin{array}{c}\text { Biomass Weight } \\
\text { (tons DM/ha) }\end{array}$} & \multicolumn{1}{c|}{$\begin{array}{c}\text { Carrying capacity **) } \\
\text { (AU) }\end{array}$} \\
\hline 1. & Scenario $1:$ crop index 1 & 35.64 & 11.34 \\
2. & Scenario $2:$ crop index 2 & 71.28 & 22.27 \\
3. & Scenario $3:$ crop index 3 & 106.92 & 33.41 \\
4. & Scenario $4:$ crop index 4 & 142.56 & 44.55 \\
\hline
\end{tabular}

Remark:

*) Every 1 crop index of maize for fresh forage needs 85 days (10 days land preliminary and 75 days appropriate harvesting time).

**) One Animal Unit ( $1 \mathrm{AU}$ ) is equal to 1 head of adult cattle which $350 \mathrm{~kg}$ body weight. The estimation of feed consumption per head per year is $3200 \mathrm{~kg}$ DM per AU.

Table 3. Estimation of carrying capacity of maize straw (DM based)

\begin{tabular}{|ll|l|l|}
\hline & $\begin{array}{c}\text { Crop index scenario } \\
\text { per year } * \text { ) }\end{array}$ & \multicolumn{1}{|c|}{$\begin{array}{c}\text { Straw Weight } \\
\text { (tons DM/ha) }\end{array}$} & \multicolumn{1}{c|}{$\begin{array}{c}\text { Carrying capacity } * *) \\
(\text { AU) }\end{array}$} \\
\hline 1. & Scenario 1: crop index 1 & 21.05 & 6.58 \\
2. & Scenario 2: crop index 2 & 42.10 & 13.16 \\
3. & Scenario 3: crop index 3 & 63.15 & 19.73 \\
4. & Scenario 4: crop index 4 & 84.20 & 26.31 \\
\hline
\end{tabular}

Remarks:

*) Every 1 crop index of maize for fresh forage need 85 days (10 days land preliminary and 75 days for plant until devaluation for fresh harvest).

**) One Animal Unit ( $1 \mathrm{AU}$ ) is equal with 1 head of adult cattle which $350 \mathrm{~kg}$ body weight. The estimation of feed consumption per head per year is $3200 \mathrm{~kg}$ DM per AU.

Furthermore, the carrying capacity of 1 ha of annual fodder plant (perennial) dwarf elephant grass on coconut plantations is $46.78 \mathrm{AU}$, while king grass is $36.63 \mathrm{AU}$ [5]. As in maize straw, King grass and dwarf elephant grass has a deficiency in carbohydrate content as an energy source, so if it is not recommended to be a single feed or complete feed.

\subsection{Productivity of maize forages}

The data on the chemical composition of forage nutrition maize forage compared to elephant grass (Pennisetum-purpureum) is shown in Table 4. Forage maize from the aspect of quality indicates several advantages over elephant grass, such as much lower in ash content $(10.20$ vs. $15.40 \%)$ and crude fibre (29.33 vs. $33.10 \%)$ and much higher in total content. digested energy or TND (58.00 vs 51.00\%). Moreover, feed ingredients with TDN content greater than $50 \%$, are classified as energy source fibre feed ingredient 17 ].

The proportion of ash content is always inversely proportional to the proportion of organic matter content of feed ingredients, meaning that the lower the ash content, the higher the organic matter content of the feed. Forage maize is classified as high organic matter contents. 
Therefore, it can fulfil one of the requirements as superior forage. The high level of TDN forage for maize feed is caused by the presence of maize grains content. According to [7] reported that the TDN content of maize grains was $80 \%$ of yellow maize and $81 \%$ of white maize.

The complete feed (concentrate) for beef cattle according to the Indonesian National Standards requires that the chemical composition of crude protein is at least $14 \%$ and TDN $65 \%$ for brooders and $12 \%$ for bulls or fattening cattle [7]. For this reason, if maize forage is used as the basic feed for beef cattle, it must be added with other feed ingredients from the protein and energy source group to achieve a TDN content of $65 \%$ For example, copra meal can be added in the feed formulation as a source of high protein and energy since contains $21-22 \%$ crude protein and $83 \%$ TDN [5]

Table 4. Nutrient composition of maize forage and elephant grass

Source: [17]

\begin{tabular}{|l|c|c|c|c|c|c|}
\hline \multirow{2}{*}{ Forages } & \multicolumn{6}{|c|}{ Nutrient composition (\%) } \\
\cline { 2 - 7 } & DM & CP & Fat & Ash & CF & TDN \\
\hline Maize & 22.0 & 8.8 & 1.9 & 10.2 & 29.6 & 58.0 \\
\hline Elephant grass & 18.0 & 9.1 & 2.3 & 15.4 & 33.1 & 51.0 \\
\hline
\end{tabular}

Table 5 is shown the comparison of nutrient productivities of maize forage and elephant grass, whereas, the amount of forage nutrition production of maize forage per production cycle per ha is calculated by the product of the amount of dry matter yield in scenario 1 growing season per year (Table 2) and the nutrient content of maize plants (Table 4). When compared with one of the conventional superior forages such as elephant grass [7] it is clear that the alternative forage maize plants have advantages in terms of the amount of production of nutrients or nutrients needed by cattle.

Table 5. Nutrient's productivity of maize forage and elephant gras (t DM/ha)

\begin{tabular}{|c|c|c|}
\hline Nutrients & Maize forage*) & Elephant grass $* *)$ \\
\hline Crud Protein, ton/ha & 2.85 & 1.33 \\
Carbohydrate, $\mathrm{t} / \mathrm{ha}$ & 17.64 & 6.40 \\
Crud Fat, ton $/ \mathrm{ha}$ & 0.68 & 0.37 \\
Ash, ton $/ \mathrm{ha}$ & 3.63 & 2.47 \\
Crus Fiber, ton $/ \mathrm{ha}$ & 10.55 & 5.30 \\
TDN, ton/ha & 20.64 & 8.17 \\
\hline
\end{tabular}

Source: *) primary data

$* *)[17]$

It can be seen in Table 6, that the performance of maize farming for forage cattle has been carried out efficiently where the $\mathrm{R} / \mathrm{C}$ value is 2.3 . This means that every rupiah (IDR) of production costs allocated to the performance of maize farming for forage cattle in North Sulawesi (location of activities) provides a gross income of IDR. 2.3 or net income of IDR. 1.3. In other words, maize farming for forage for cattle in North Sulawesi, if managed effectively, becomes a business field for farmers in North Sulawesi. It can be sold to other farmers for feed. 
Table 6. Financial analysis of maize forage farming as feed per (Ha)

\begin{tabular}{|l|l|l|l|l|l|}
\hline No. & Item & Total & unit & $\begin{array}{l}\text { Price per } \\
\text { unit (IDR) }\end{array}$ & Value (IDR) \\
\hline I & Revenue: & & & & \\
\hline & 1.1. Fresh Maize biomass & 142 & Row & 100,000 & $14,200,000$ \\
\hline II & Cost: & & & & $6,250,000$ \\
\hline & 2.1. Labour: & & & & \\
\hline & a. Land preliminary & 14 & Man & 125,000 & $1,750,000$ \\
\hline & b. Planting & 6 & Man & 125,000 & 750,000 \\
\hline & c. Fertilization 1 & 6 & Man & 125,000 & 750,000 \\
\hline & d. Fertilization 2 & 6 & Man & 125,000 & 750,000 \\
\hline & e. Weeding 1 & 6 & Man & 125,000 & 750,000 \\
\hline & f. Weeding 2 & 6 & Man & 125,000 & 750,000 \\
\hline & 2.2. Production cost: & & & & \\
\hline & a. Urea fertilizer & 1 & bag & 100,000 & 100,000 \\
\hline & b. NPK fertilizer & 2.5 & bag & 140,000 & 350,000 \\
\hline c. Seed maize & 20 & kg & 15,000 & 300,000 \\
\hline III & Net Income (I - II) $=$ III & & & & $7,950,000$ \\
\hline IV & ROI $=(\mathrm{I} /$ II) X 100 & & & & 2.27 \\
\hline V & R/C $=(\mathrm{I} /$ II) & & & & 2.3 \\
\hline
\end{tabular}

\section{Conclusion}

Maize can be arranged as an alternative forage to support the development of beef cattle farming since the area has insufficient grazing land due to its potency to produce high amounts of biomass and nutrient contents. This is indicated by the productivity of dry matter, crude protein, the amount of digested nutrients, and carbohydrates which are much higher than conventional superior forage feeds. The introduction of maize cultivation innovations, IPM for forage purposes is feasible. For one production season, 75 days, it could be produced 35.64 tons of DM or equivalent to feed needs of 11.34 AU throughout the year, while a year has the potential to reach 4 cycles to supply feed of $44.55 \mathrm{AU}$ per ha per year. Whereas, it could be reached if irrigation is available in the dry season. The results of the financial analysis of maize farming as forage is profitable and financially feasible. The performance of maize farming as a forage source, especially cattle in North Sulawesi is also efficient as indicated by the value of the Revenue Cost Ratio which is greater than 1.00.

\section{References}

1. Kementan RI. 2018. Peraturan Menteri Pertanian Republik Indonesia Nomor 472/RC.040/6/2018. Kementan RI

2. BPS Sulut. https://sulut.bps.go.id/indicator/24/171/1/populasi-ternak-menurutkabupaten-kota-dan-jenis-ternak-di-sulawesi-utara.html

3. BPS Sulut. 1993. Sulawesi Utara Dalam Angka. Biro Pusat Statistik Sulawesi Utara dan Badan Perencanaan Pembangunan Daerah Sulawesi Utara. Manado

4. Paat, P.C., J.W. Rembang, D. Polakitan, A.Kairupan, J. Wenas, Mardiana, dan R.R. Ifada. 2019. Model Pertanian Bioindustri Integrasi Jagung-Sapi Di Sulawesi Utara. Laporan Hasil Pengkajian BPTP Sulut.

5. P.C Paat., J.G. Kindangen. Bulletin of Palmae, 17, 1 (2016)

6. Puslitbangtan. Inovasi Unggulan Tanaman Pangan Berbasis Agroekosistem Mendukung Prima Tani. Puslitbangtan, Badan Litbang Pertanian. Jakarta. (2006) 
7. BSN. Standar Nasional Indonesia untuk pakan lengkap (konsentrat) sapi potong. Badan Standar Nasional Indonesia. Jakarta.( 2009)

8. Pranata, R.A. 2012. Metode Kuadran dan Garis. http://rianbio. wordprss. com/2012/07 /23/metode-kuadran-dan-garis/

9. Hendayana, R. Analisis Data Pengkajian. Cerdas dan Cermat Menggunakan Alat Analisis Data. IAARD Press. Jakarta. (2016)

10. Suratiyah, K.,. Ilmu Usahatani. Penerbit Penebar Swadaya (2008)

11. Widiyanto. Prilaku Petani terhadap Riziko Pilihan Pola Tanam di Desa Wukirsari Kecamatan Cangkingan, KabupatenSleman. Thesis. Program Pascasarjana UGM, Yogyakarta. (2001)

12. R, Hendayana. Analisis Data Pengkajian. Cerdas dan Cermat Menggunakan Alat Analisis Data. IAARD Press. Jakarta. (2016)

13. Mahardika and Farida. Analisis Pengembangan Usaha Pemanfaatan Limbah Bonggol Jagung Menjadi Produk Kerajinan Multiguna. J Manajemen dan Organiasasi 53214

14. Rakhmawari, D. Analisis return on investment (roi) untuk mengukur kemampuan menghasilkan laba (Studi Kasus di PT. Tainesia Jaya Surakarta). Skripsi (2009)

15. H.,Hartadi, R. Soedomo, dan A.D. Tillma. Tabel Komposisi Pakan Untuk Indonesia. Gadjah Mada Univ. Press. (1997)

16. Subandi, S. Saenong, Bahtiar, I.U. Firmansyah, dan Zubachtirodin. 2004. Peranan Penelitian Jagung dalam Upaya Mencapai Swasembada Jagung Nasional. Makalah disampaikan pada Seminar Nasional Peranan Agro Inovasi Mendukung Ketahanan Pangan dan Agribisnis. Sumatera Barat. 10 Agustus 2004

17. Utomo, R. Bahan Pakan Berserat untuk sapi. Penerbit PT. Citra Aji Parama. Yogyakarta (2012) 